\title{
Ice Nucleation, Freezing Injury, and Colonization of 'Totem' Strawberry Flowers with Ice-nucleation- active (INA) Bacteria
}

\author{
Michele R. Warmund ${ }^{1}$ and James T. English ${ }^{2}$ \\ University of Missouri, Columbia, MO 65211
}

Additional Index wonds. Fragaria Xananassa, Pseudomonas syringae, cold hardiness, thermal analysis, freezing properties

\begin{abstract}
INA bacteria were isolated from primary flowers of 'Totem' strawberry (Fragaria $\times$ ananassa Duch.) plants that had been previously inoculated with strain Cit 7 of Pseudomonas syringae van Hall or noninoculated to determine their relationship to ice-nucleation temperature and floral injury. Mean ice-nucleation temperature of inoculated and noninoculated flowers was -2.2 and $-2.8^{\circ} \mathrm{C}$, respectively. Primary flowers of noninoculated plants survived lower temperatures than those of inoculated plants. In another experiment, noninoculated plants were misted with sterile deionized water and incubated for $0,12,24,36$, or 48 hours at $25^{\circ} \mathrm{C}$ day/10 ${ }^{\circ} \mathrm{C}$ night, and naturally occurring INA bacteria were isolated from primary flowers. INA bacterial densities increased exponentially with increasing incubation period. The critical wetness period for INA bacteria to establish a sufficient density to increase the likelihood of floral injury at $-2.5^{\circ} \mathrm{C}$ was 24 hours. Longer wetness periods resulted in higher INA bacterial densities but did not increase the floral mortality rate. Thermal analysis demonstrated that the ice nucleation temperature was associated with strawberry floral injury. Thus, low temperature survival of flowers was adversely affected by moisture for $\geq \mathbf{2 4} \mathrm{h}$ due to the presence of a sufficient density of INA bacteria to incite ice formation and floral injury.
\end{abstract}

Frost injury to strawberry flowers can limit full yield potential (Janick and Eggert, 1968). Fruit number and mass are substantially reduced when primary flowers are injured (Janick and Eggert, 1968). Boyce et al. (1985) reported that yield was decreased by $30 \%$ when primary flowers of strawberry plants were removed during early bloom.

Strawberry floral injury generally occurs over a range of temperatures ( $\mathrm{Ki}$ and Warmund, 1992). While some flowers are injured at $-2.2^{\circ} \mathrm{C}$, others supercool and survive lower temperatures (Anderson and Whitworth, 1993; Boyce and Strater, 1984). Results of previous research suggest that certain species of bacteria colonize the surfaces of plants and contribute to frost injury by serving as nuclei for ice crystal formation (Lindow, 1983; Lindow et al., 1982a; Maki et al., 1974). INA bacteria, such as Pseudomonas syringae and Erwinia herbicola (Löhnis) Dye, initiate frost damage at temperatures above those at which noncolonized plants would normally freeze (Anderson and Ashworth, 1985; Lindow et al., 1978b).

INA bacteria have been isolated from the foliage of strawberry and many other types of plants in the field (Lindow et al., 1978a). Naturally occurring populations of INA have also been recovered from sweet cherry and peach flowers (Andrews et al., 1986; Gross et al., 1984). Following bloom, cherry and peach floral tissues that had been separated from stem tissue had greater injury in the presence of INA bacteria (Gross et al., 1984). There are some reports that INA bacteria, when applied to strawberry flowers, raise the temperature at which ice forms; but, in these cases, flowers were inoculated with very large numbers of bacteria (Anderson and Whitworth, 1993; Lindemann and Suslow, 1987). Anderson and Whitworth (1993) found that strawberry flower pedicels froze at $\approx 2{ }^{\circ} \mathrm{C}$ higher after inoculation with Erwinia

Received for publication 10 July 1997. Accepted for publication 6 Oct. 1997. Missouri Agricultural Experiment Station journal series no. 12,663. The cost of publishing this paper was defrayed in part by the payment of page charges. Under postal regulations, this paper therefore must be hereby marked advertisement solely to indicate this fact.

${ }^{1}$ Associate professor, Dept. of Horticulture.

${ }^{2}$ Associate professor, Dept. of Plant Pathology. herbicola, but they did not evaluate injury resulting from freezing. Consequently, it is unknown if frost injury to strawberry flowers is associated directly with the presence of naturally occurring INA bacteria. Therefore, the objectives of these studies were to 1) determine if naturally occurring INA bacteria colonize strawberry flowers; 2) ascertain the temperatures at which different densities of INA bacteria incite ice crystallization on flowers; and 3) determine if there is a relationship between densities of INA bacteria on strawberry flowers and floral injury.

\section{Materials and Methods}

Dormant 'Totem' strawberry plants were obtained from a commercial nursery, sealed in bags, and stored at $3{ }^{\circ} \mathrm{C}$ for up to 2 months until experiments were initiated. For each experiment, cold-stored crowns were planted in Pro-mix BX (Premier Brands, Stamford, Conn.) in 10-cm-diameter (0.64-L) containers. Potted crowns were then placed in a growth chamber at $85 \%$ relative humidity $(\mathrm{RH}), 25^{\circ} \mathrm{C}$ day $/ 10^{\circ} \mathrm{C}$ night cycle, with a $14-\mathrm{h}$ photoperiod at a photosynthetic photon flux (PPF) of $500 \mu \mathrm{mol} \cdot \mathrm{m}^{-2} \cdot \mathrm{s}^{-1}$ at canopy level. Plants were routinely irrigated from below to avoid wetting leaves. When plants had flowers at first white stage (petals exposed but still incurved), they were selected for use in the experiments.

\section{Experiment 1}

ISOLATING NATURALLY OCCURRING BACTERIA AFTER $0,12,24,36$, OR 48 H OF PLANT WETNESS. A preliminary experiment was conducted to determine if the density of naturally occurring INA bacteria on 'Totem' strawberry flowers was influenced by the period of floral wetness. When flowers were at the first white stage, six plants were selected for each of the wetness periods and were misted with $\approx 5$ $\mathrm{mL}$ sterile deionized water, placed in sealed plastic bags, and incubated in the growth chamber for $0,12,24,36$, or $48 \mathrm{~h}$. After incubation, plants were removed from the chamber and individual primary flowers were placed in test tubes with $0.1 \mathrm{~m}$ phosphate buffer $(\mathrm{pH} \mathrm{7.0)}$ and vortexed for $1 \mathrm{~min}$. The flower was then removed, and isolated bacteria were collected by centrifugation of 
the buffer suspension at $3000 \mathrm{~g}_{\mathrm{n}}$ for $10 \mathrm{~min}$. To quantify bacteria, the pellet was resuspended in phosphate buffer, diluted serially, and plated on nutrient agar (Difco, Detroit) supplemented with $2.5 \%$ glycerol (v/v) and $100 \mathrm{ppm}$ cycloheximide (NAGC medium) (Lindow et al., 1978a). After plates were incubated at $25^{\circ} \mathrm{C}$ for 48 $\mathrm{h}$, bacterial colonies were counted directly from NAGC plates. The INA fraction of these colonies was estimated by the plate-harvesting technique (Anderson and Ashworth, 1985; Warmund and English, 1995). To harvest the bacteria, each petri dish was flooded with $5 \mathrm{~mL}$ sterile deionized water. Each bacterial suspension was then placed in a test tube that was submerged in a refrigerated bath at $-3{ }^{\circ} \mathrm{C}$. After $30 \mathrm{~min}$ at $-3^{\circ} \mathrm{C}$, the bath was adjusted to $-5^{\circ} \mathrm{C}$ and test tubes were held at this temperature for $30 \mathrm{~min}$. Bacterial suspensions that froze at either of the test temperatures were considered to contain INA bacteria. The highest dilution at which a suspension froze was used to provide an order-of-magnitude estimation of INA bacterial density (Anderson and Ashworth, 1985; Anderson et al., 1987). This method was used because of its capacity to detect low densities of INA bacteria (Anderson and Ashworth, 1985; Anderson and Whitworth, 1993). The limit of detection of this assay was 125 colony-forming units (CFU)/g tissue dry mass.

To assess the effect of the wetness period on INA bacterial densities, data were subjected to an analysis of variance (ANOVA) and linear and quadratic polynomial contrasts were determined (SAS Institute, Cary, N.C.). Bartlett's test verified the existence of heterogeneous variance (Snedecor and Cochran, 1989). Thus, all bacterial data were $\log _{10}$ transformed.

\section{Experiment 2}

INOCULATING FLOWERS WITH INA BACTERIA. Two bacterial densities were established on primary flowers of strawberry plants. Strain Cit 7 of $P$. syringae was used to inoculate flowers of 28 plants. Bacteria were grown in nutrient broth at $\approx 25^{\circ} \mathrm{C}$. After 24 $\mathrm{h}$ on an orbital shaker at $100 \mathrm{rpm}$, bacterial cultures were centrifuged at $5000 \mathrm{rpm}$ for $10 \mathrm{~min}$. The pellet of bacteria was resuspended in $0.1 \mathrm{M}$ phosphate buffer and adjusted to an optical density of 0.2 at $600 \mathrm{~nm}\left(\approx 10^{8}\right.$ cells/mL). The culture was further diluted with $0.1 \mathrm{M}$ phosphate buffer $(\mathrm{pH} 7.0)$ to a density of $10^{6}$ cells $/ \mathrm{mL}$. To establish a high density of INA bacteria on floral tissue, bacterial suspensions were then applied with a chromatography sprayer to primary flowers at first white stage. About $0.7 \mathrm{~mL}$ of bacterial suspension was applied to the inflorescence of each plant. Inoculated plants were placed inside sealed plastic bags and then placed in the growth chamber for $48 \mathrm{~h}$. To establish a low density of bacteria, primary flowers of 28 plants were sprayed with only sterile deionized water, not bagged, and placed inside the growth chamber for $48 \mathrm{~h}$.

ASSESSING ICE NUCLEATION TEMPERATURES AND FLORAL INJURY OF INOCULATED AND NONINOCULATED FLOWERS. After incubation in the growth chamber for $48 \mathrm{~h}$, plant roots were washed free of potting medium and a 0.01-mm-diameter (30-gauge) copper-constantan thermocouple was attached to the base of the primary flower to monitor tissue temperature during lowtemperature exposure. Plants were then wrapped in moist cheesecloth. As plants were wrapped, leaves were kept away from the primary flower to ensure that they did not contact the thermocouple. Moist cheesecloth was used to seed the floral tissue with ice during low-temperature exposure (Burke et al., 1976; Warmund et al., 1992). After plants were wrapped, they were placed in glass test tubes and submerged in a recirculating ethylene glycol bath (NESLAB Instruments, Newington, N.H.) precooled to $0^{\circ} \mathrm{C}$. Samples were held at $0^{\circ} \mathrm{C}$ for $\mathrm{I} \mathrm{h}$ and then cooled at $1^{\circ} \mathrm{C} \cdot \mathrm{h}^{-1}$. Seven plants of each treatmenttemperature combination were removed from the freezer when the tissue temperatures were $-2.0,-2.5,-3.0$, or $-3.5^{\circ} \mathrm{C}$. Samples were placed in a refrigerator at $2^{\circ} \mathrm{C}$ and allowed to thaw slowly for $24 \mathrm{~h}$. Thermocouple output was recorded at $40-$ s intervals on a data logger (CR-10; Campbell Scientific, Logan, Utah). Data from each flower were then plotted, and the temperature at which there was a large deflection from the baseline of the thermal analysis curve was considered to be the ice-nucleation temperature (Anderson and Ashworth, 1985). To assess floral injury, receptacles of strawberry flowers were examined for oxidative browning at $\approx 6 \mathrm{~h}$ after thawing (Ki and Warmund, 1992).

About $24 \mathrm{~h}$ after samples were exposed to subfreezing temperatures, INA bacteria were isolated from strawberry flowers and their densities were estimated as previously described. Because of equipment limitations, this experiment (seven replications of each of the eight treatment combinations) was conducted twice. To evaluate the effect of INA bacterial density on ice-nucleation temperature, data from each experiment were subjected to ANOVA. However, because the ice-nucleation temperatures did not differ among experiments, data were pooled for statistical analysis. Because ice nucleation was not detected from any of the inoculated samples subjected to $-2.0^{\circ} \mathrm{C}$, data from this temperature treatment were omitted. Trend analysis was performed on the remaining nucleation data. Floral injury data were subjected to a row by column chi-square test to dctcrmine differences among flower exposure temperatures (Snedecor and Cochran, 1989).

\section{Experiment 3}

ASSESSING FLORAL INJURY IN RELATION TO DENSITY OF NATURALLY OCCURRING INA BACTERIA. To determine if there was a relationship between density of INA bacteria on strawberry flowers and floral injury, a range of floral bacterial densities was established by varying the wetness period as described in Expt. 1. Crowns were potted and grown in a growth chamber as described above. When primary flowers were at the first white stage, eight plants for each of the incubation periods were misted with $\approx 5 \mathrm{~mL}$ of sterile water, placed in sealed plastic bags, and incubated in the growth chamber for $0,12,24,36$, or 48 h at $25^{\circ} \mathrm{C}$ day $/ 10^{\circ} \mathrm{C}$ night cycle, with a 14 -

Fig. 1. Densities of naturally occurring INA bacteria (CFU/g dry mass floral tissue) recovered from primary flowers of 'Totem' strawberry plants after $0,24,36$, or $48 \mathrm{~h}$ of plant wetness.

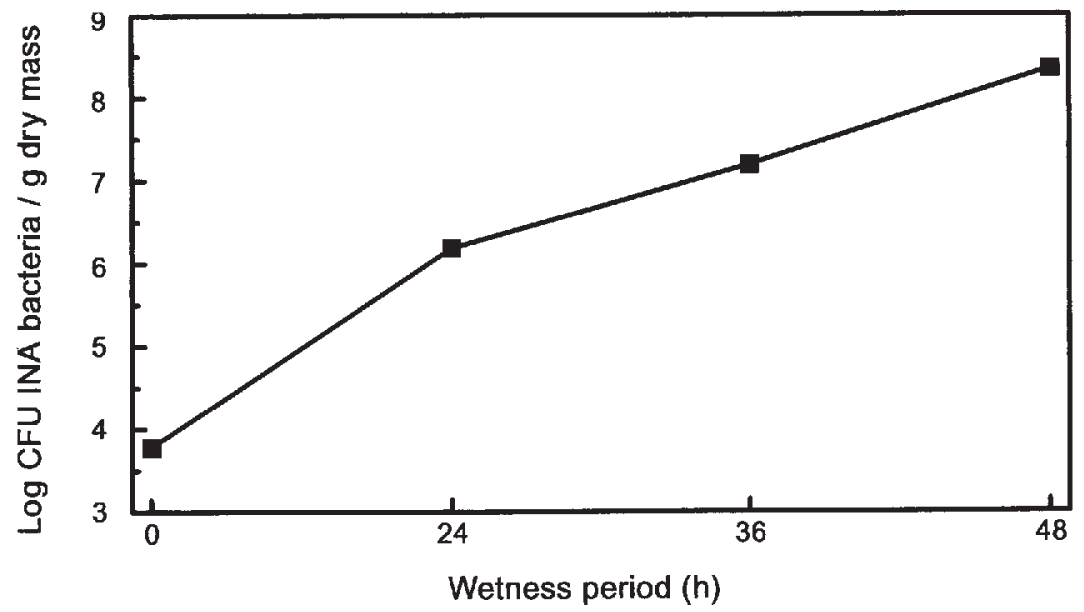


Table 1. Ice nucleation temperatures of inoculated and noninoculated 'Totem' strawberry flowers and the number of flowers that exhibited oxidative browning injury in the receptacle tissue after low temperature exposure.

\begin{tabular}{|c|c|c|c|c|}
\hline \multirow{3}{*}{$\begin{array}{l}\text { Flower exposure } \\
\text { temp }\left({ }^{\circ} \mathrm{C}\right)\end{array}$} & \multicolumn{2}{|c|}{ Ice nucleation temp $\left({ }^{\circ} \mathrm{C}\right)^{\mathrm{z}}$} & & \\
\hline & \multirow{2}{*}{$\begin{array}{l}\text { Inoculated } \\
\text { flowers }\end{array}$} & \multirow{2}{*}{$\begin{array}{l}\text { Noninoculated } \\
\text { flowers }\end{array}$} & \multicolumn{2}{|c|}{ Injured flowers (no.) } \\
\hline & & & Inoculated $^{y}$ & Noninoculated \\
\hline-2.0 & $--(0)^{x}$ & $-1.9(1)$ & 0 & $\overline{1}$ \\
\hline-2.5 & $-2.2(10)$ & $-2.0(1)$ & 11 & 1 \\
\hline-3.0 & $-2.2(14)$ & $-2.7(3)$ & 14 & 3 \\
\hline-3.5 & $-2.2(14)$ & $-2.8(10)$ & 14 & 11 \\
\hline
\end{tabular}

Significance NS L

\footnotetext{
${ }^{2}$ Data from noninoculated flowers exposed to $-2^{\circ} \mathrm{C}$ were omitted from the analysis because ice nucleation was not detected from inoculated flowers subjected to $-2{ }^{\circ} \mathrm{C}$.

y Flowers were inoculated with $P$ seudomonas syringae strain Cit 7 at $10^{6}$ bacterial cells $/ \mathrm{mL}$.

xParenthetical value is the number of flowers that exhibited a low temperature exotherm, $n=14$.

ss Nonsignificant as determined by trend analysis at $P \leq 0.05 ; \mathrm{L}=$ linear.
}

h photoperiod at a PPF of $500 \mu \mathrm{mol} \cdot \mathrm{m}^{-2} \cdot \mathrm{s}^{-1}$ at canopy level. After incubation, plants were removed from the chamber and prepared for low-temperature exposure as previously described to determine the ice-nucleation temperature and evaluate floral injury. Samples were placed in a recirculating bath precooled to $0^{\circ} \mathrm{C}$, held at this temperature for $1 \mathrm{~h}$, and then cooled at $1{ }^{\circ} \mathrm{C} \cdot \mathrm{h}^{-1}$. When the receptacle tissue was $-2.5^{\circ} \mathrm{C}$, individual samples were removed from the bath and placed in a refrigerator at $2{ }^{\circ} \mathrm{C}$ to thaw slowly for $24 \mathrm{~h}$. Because $-2.5^{\circ} \mathrm{C}$ was the critical temperature at which injury of inoculated flowers occurred in Expt. 2 (Table 1), samples were exposed to this temperature in Expt. 3. Receptacle temperatures were logged during the experiment, floral injury was evaluated, and bacteria were isolated as described above. This experiment was performed twice, and because data for each experiment did not differ, they were pooled for statistical analyses. Trend analysis was performed on bacterial density data after $\log _{10}$ transformation, and floral injury data were evaluated by row by column chi-square analysis.

\section{Results}

RECOVERING NATERALIY OCCURRING BACTERIA AFTER 0, 12, 24, 36, OR $48 \mathrm{H}$ OF PLANT WETNESS. INA bacteria were recovered from $57 \%$ of the all flowers sampled ( 0 to $48 \mathrm{~h}$ of plant wetness). INA bacterial densities on flowers increased exponentially with the duration of plant wetness (Fig. 1). At the time of initial wetting $(0 \mathrm{~h})$, the mean bacterial density was $6000 \mathrm{CFU} / \mathrm{g}$ dry mass of floral tissue. INA bacteria were not recovered from any of the flowers sampled at $12 \mathrm{~h}$ of plant wetness due to a technical problem in plating. However, after $24 \mathrm{~h}$ of plant wetness, bacterial densities increased at a rate of at least 10 -fold at each sampling time. Thus, results from this initial experiment verified the natural occurrence of INA bacteria on strawberry flowers and indicated that the density of INA bacteria increased with an increasing period of wetness.

Determining Bacterial Densities, ICE NUCLEATION, AND FLORAL INJURY OF INOCULATED AND NONINOCULATED PLANTS. Strawberry flowers that were inoculated with INA bacteria and maintained at high plant surface wetness in bags had higher bacterial densities than noninoculated flowers on plants that were maintained at low surface wetness under ambient conditions (not sealed in bags). The mean density of INA bacteria that colonized strawberry flowers 48 $\mathrm{h}$ after inoculation was $1.3 \times 10^{9} \mathrm{CFU} / \mathrm{g}$ dry mass of floral tissue. In contrast, the mean density of INA bacteria on noninoculated samples was $2.8 \times 10^{4} \mathrm{CFU} / g$ dry mass. Although INA bacteria were recovered from all inoculated flowers, they were isolated from only $61 \%$ of the noninoculated flowers.

Ice nucleation was not detected from any of the inoculated flowers exposed to $-2.0^{\circ} \mathrm{C}$ (Table 1). However, one freezing event (cxotherm) was detected per inoculated flower during exposure to temperatures lower than $-2.0^{\circ} \mathrm{C}$ (Fig. 2). Ice nucleation was detected from -1.9 to $-2.5^{\circ} \mathrm{C}$ on inoculated flowers cooled to $-2.5,-3.0$, or $3.5^{\circ} \mathrm{C}$ (Table 1$)$. The mean ice-nucleation temperature for inoculated samples exposed to test temperatures below $-2.0^{\circ} \mathrm{C}$ was $-2.2^{\circ} \mathrm{C}$. In contrast, ice nucleation was detected in only a few of the noninoculated flowers exposed to test temperatures of $-2.0,-2.5$, or $-3.0{ }^{\circ} \mathrm{C}$. However, nucleation was detected in $71 \%$ of the noninoculated flowers cooled to $-3.5^{\circ} \mathrm{C}$ (Table 1, Fig. 3). Although the mean ice-

Fig. 2. Thermal analysis of a primary flower of 'Totem' strawberry that was inoculated with Pseudomonas syringae strain Cit 7 at $10^{6}$ bacterial cells $/ \mathrm{mL}$ and maintained in a wet environment.

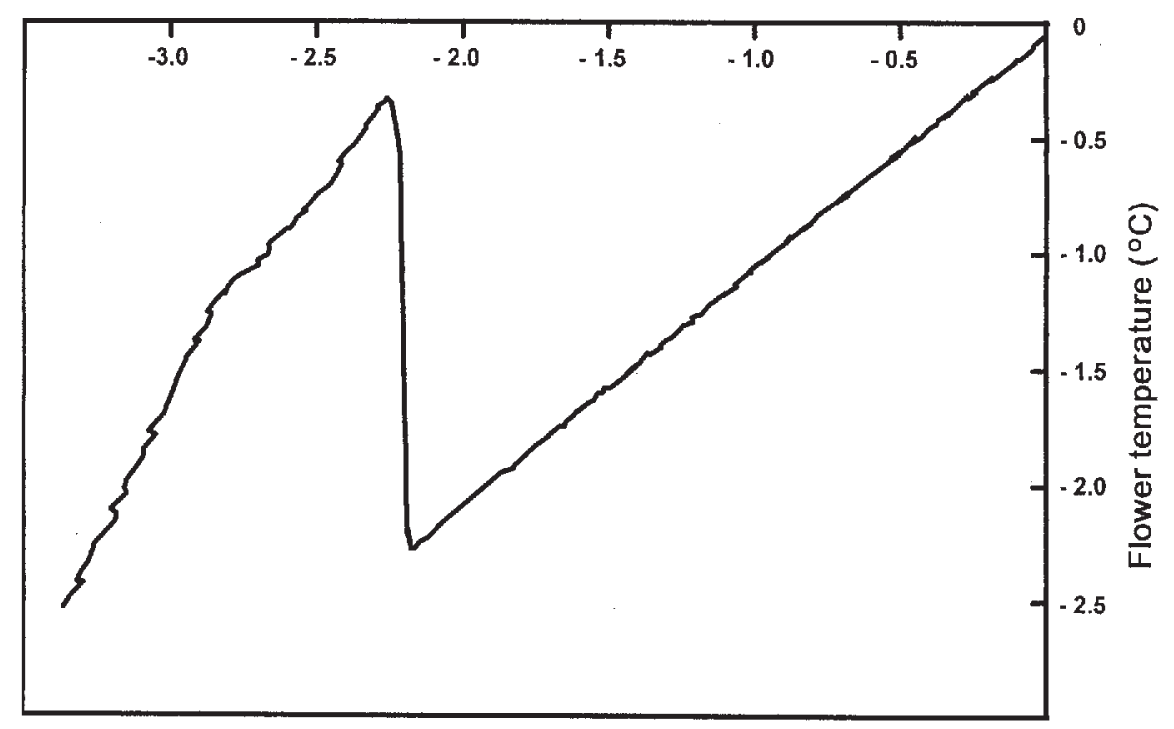

Bath temperature $\left({ }^{\circ} \mathrm{C}\right)$ 


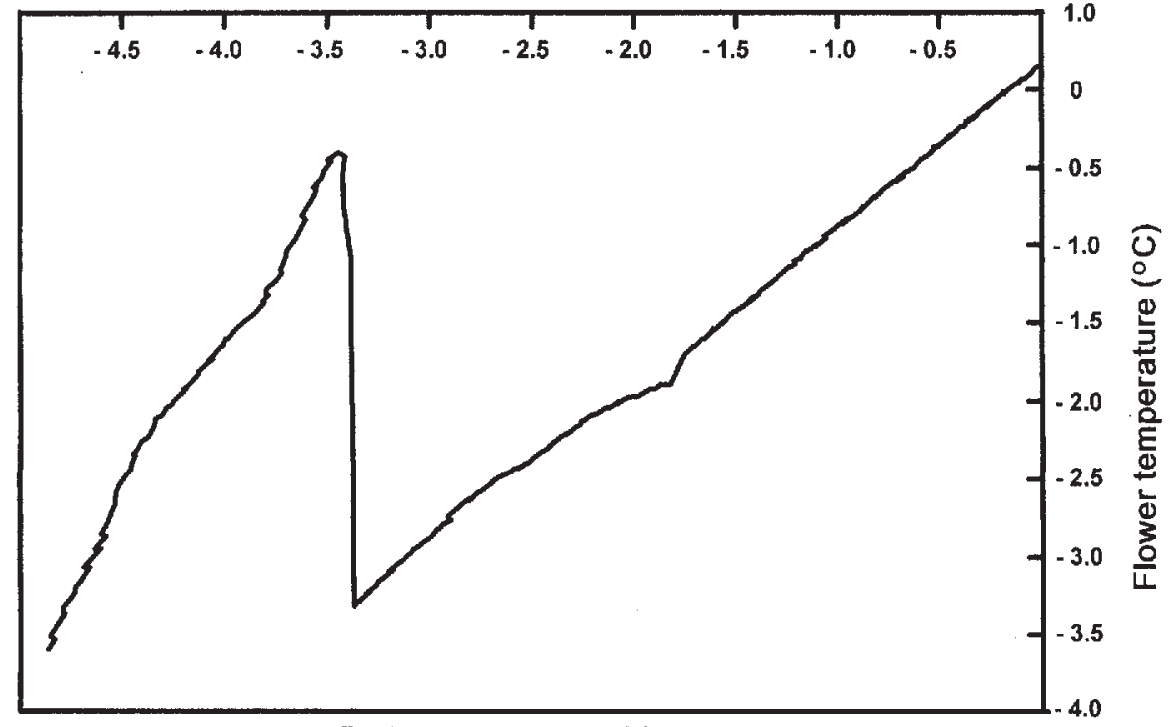

Bath temperature $\left({ }^{\circ} \mathrm{C}\right)$

Fig. 3. Thermal analysis of a primary flower of 'Totem' strawberry that was not inoculated with $P$. syringae and was maintained in a dry environment.

nucleation temperature of noninoculated flowers exposed to $-3.5^{\circ} \mathrm{C}$ was $-2.8^{\circ} \mathrm{C}$ (Table 1 ), the range of nucleation temperatures was -2.0 to $-3.4{ }^{\circ} \mathrm{C}$. Thus, the mean nucleation temperature of inoculated flowers remained constant when they were exposed to lower than or equal to $-2{ }^{\circ} \mathrm{C}$. In contrast, the mean ice-nucleation temperature of noninoculated flowers decreased linearly as the exposure temperature decreased to $-3{ }^{\circ} \mathrm{C}$.

More than $75 \%$ of the flowers inoculated with INA bacteria were injured after exposure to $-2.5^{\circ} \mathrm{C}$ (Table 1). Moreover, none of the inoculated flowers survived exposure to -3.0 or $-3.5^{\circ} \mathrm{C}$. Compared to inoculated flowers, fewer noninoculated flowers were injured by exposure to -2.5 and $-3.0^{\circ} \mathrm{C}\left(\chi^{2}=12\right.$ and 15 , respectively, $P<0.01)$. Additionally, $21 \%$ of the noninoculated flowers survived low-temperature exposure to $-3.5^{\circ} \mathrm{C}$.

ASSESSING FLORAL INJURY IN RELATION TO DENSITY OF INA BACTERIA RECOVERED AFTER EXPOSURE TO $\mathbf{- 2 . 5}{ }^{\circ} \mathrm{C}$. INA bacteria were recovered from few of the flowers that were wet for 0 or $12 \mathrm{~h}$, but INA bacteria were isolated from $\geq 50 \%$ of the flowers that were wet for 24,36 , or $48 \mathrm{~h}$ (Table 2). Densities of INA bacteria recovered from strawberry flowers increased exponentially up to $48 \mathrm{~h}$ of plant wetness (Table 2). The mean density of INA bacteria isolated from primary flowers after $48 \mathrm{~h}$ of wetness was $1.6 \times 10^{7} \mathrm{CFU} / \mathrm{g}$ dry mass.

Each primary flower from which ice nucleation was detected also exhibited oxidative browning injury. However, ice-nucleation temperature and floral injury differed in their responses to the wetness period to which flowers were exposed. The mean ice-nucleation temperature of strawberry flowers was similar among flowers from all wetness periods (Table 2). In contrast to the ice-nucleation temperature, floral injury at $2.5^{\circ} \mathrm{C}$ increased with increasing wetness period up to $24 \mathrm{~h}$ wetness (Table 2). However, the percentage of floral damage did not increase beyond $24 \mathrm{~h}$ of wetness.

\section{Discussion}

Naturally occurring INA bacteria were recovered from primary flowers of plants produced from cold-stored strawberry crowns that were grown in a growth chamber. INA bacterial populations remained low when plants were maintained in a dry environment. In contrast, the log of INA bacterial densities increased linearly during 48 h of plant wetness (Table 2 ). During the 48 -h period, there was no indication that the bacterial carrying capacity of the floral tissues had been attained.

Estimations of INA bacterial densities varied among experiments, depending on when bacteria were isolated from flowers. Although results from the different experiments cannot be directly compared, more INA bacteria tended to be recovered from flowers before low-temperature exposure (Fig. 1) than after exposure (Table 2). In different experiments, bacterial densities from a common treatment varied by up to 24 -fold. It is not known if differences between population estimates were related to variations in colonization patterns of plants lifted from the field, temperature treatment, and/or the 24-h delay before isolation in the different experiments. There was also a potential for differences in population estimates that were derived from the plate-harvesting method used for isolating and quantifying INA bacteria. Regardless of differences in population densities detected by the different isolation methods, similar exponential patterns of population increase were observed with increasing wetness period. In future studies, isolation methods will have to be selected with consideration to the specific use of population data.

Ice nucleation on strawberry flowers was detected from -1.9 to $-3.4{ }^{\circ} \mathrm{C}$ by thermal analysis. Results from the thermal analyses showed that only one freezing event per flower occurred during low-temperature exposure (Figs. 2 and 3). This exotherm represented ice nucleation (Anderson and Ashworth, 1985) and the

Table 2. Densities, ice nucleation temperatures, and percent floral injury of naturally occurring INA bacteria isolated from 'Totem' strawberry flowers after various incubation periods and exposure to $-2.5^{\circ} \mathrm{C}$.

\begin{tabular}{lccc}
\hline \hline $\begin{array}{l}\text { Plant wetness } \\
\text { period }(\mathrm{h})\end{array}$ & $\begin{array}{c}\text { INA bacteria } \\
(\log \mathrm{CFU} / \mathrm{g} \text { dry mass floral tissue })^{z}\end{array}$ & $\begin{array}{c}\text { Ice nucleation } \\
\text { temp }\left({ }^{\circ} \mathrm{C}\right)\end{array}$ & $\begin{array}{c}\text { Injured } \\
\text { flowers }\end{array}$ \\
\hline 0 & 3.31 & $-2.2(2)^{y}$ & 2 \\
12 & 4.83 & $-2.3(4)$ & 4 \\
24 & 4.92 & $-2.3(10)$ & 10 \\
36 & 5.76 & $-2.3(8)$ & 8 \\
48 & 7.21 & $-2.2(8)$ & 8 \\
Significance & $\mathrm{L}$ & &
\end{tabular}

${ }^{2}$ Mean densities (CFU) of INA bacteria as determined by the plate harvesting method. $\mathrm{L}=$ linear response as determined by trend analysis at $P \leq 0.05$.

'Parenthetical value is the number of flowers that exhibited ice nucleation and had detectable densities of INA bacteria, $\mathrm{n}=14$. 
temperature at which floral injury occurred. Almost all the flowers that exhibited ice nucleation also exhibited floral injury (Tables 1 and 2). In the few cases where ice nucleation was not detected from injured flowers, it is likely that the thermocouple slipped off the surface of the flower as it was inserted into the test tube in preparation for low-temperature exposure.

Populations of INA bacteria on strawberry flowers could be increased either by inoculating them with a bacterial suspension or by maintaining free moisture on floral surfaces. Densities of INA bacteria were increased sufficiently by either method to reduce the tolerance of flowers to low-temperature exposure. The proportion of flowers that were damaged at $-2.5^{\circ} \mathrm{C}$ increased with increasing wetness period up to $24 \mathrm{~h}$, after which no additional floral damage occurred. The INA bacterial density of $8.3 \times 10^{4} \mathrm{CFU} / \mathrm{g}$ dry mass of floral tissue after $24 \mathrm{~h}$ of wetness may represent a density at which the likelihood of floral injury is increased. However, this density is probably underestimated because isolations were made from floral tissue following low-temperature exposure and a 24-h delay. Others have suggested that a threshold level of INA bacteria is necessary to significantly increase the number of ice nuclei on plant tissues (Anderson etal., 1987; Hirano et al., 1985; Maki etal., 1974). Despite the difficulty in estimating the INA bacterial densities before subjecting the sample to low temperatures and the need to sacrifice the flower to determine injury, the survival of strawberry flowers during exposure to subfreezing temperatures was adversely affected by moisture before low-temperature exposure and INA bacteria colonization.

When there was an insufficient density of INA bacteria to incite ice nucleation at about $-2.2^{\circ} \mathrm{C}$, strawberry flowers supercooled to a lower temperature before ice nucleation and floral injury occurred (Table 1). In this case, nonbacterial sources of ice nuclei most likely induced ice formation in strawberry flowers. Other researchers concluded that, in the absence of detectable levels of INA bacteria on the surface of peach and sweet cherry flowers, ice nucleation at -4 to $-6{ }^{\circ} \mathrm{C}$ was caused by nucleators of plant origin (Andrews et al., 1986; Gross et al., 1984). While intrinsic ice nucleators were not identified in our study, nucleation observed at lower than $-2.3{ }^{\circ} \mathrm{C}$ may have been caused by these agents (Tables 1 and 2).

In conclusion, this study is the first work that demonstrates a relationship between density of INA bacteria, ice nucleation, and strawberry floral injury. Previous work on strawberry (Anderson and Whitworth, 1993) and peach and sweet cherry flowers only addressed ice nucleation in relation to a single, high (Gross et al., 1984) or low (Andrews et al., 1986) density of INA bacteria. In future studies, the relationship of INA bacterial density, temperature, and floral injury should be determined since the growth rate of an INA bacterial species in culture is affected by temperature (Lindow et al., 1982b). Consequently, the density of INA on strawberry flowers in the field will likely be affected by the interaction of wetness period and ambient temperature. Once this relationship is elucidated, a forecasting model could be developed that would predict when strawberry flowers colonized with INA bacteria would be injured. Using this model, growers could apply protective chemicals or use other cultural methods to prevent frost injury on strawberry flowers.

\section{Literature Cited}

Anderson, J.A. and E.N. Ashworth. 1985. Ice nucleation in tomato plants. J. Amer. Soc. Hort. Sci. 110:291-296.

Anderson, J.A., E.N. Ashworth, and G.A. Davis. 1987. Nonbacterial ice nucleation in peach shoots. J. Amer. Soc. Hort. Sci. 112:215-218.

Anderson, J.A. and J. Whitworth. 1993. Supercooling strawberry plants inoculated with ice-nucleation-active bacteria and treated with Frostgard. HortScience 28:828-830.

Andrews, P.K., E.L. Proebsting, Jr., and D.C. Gross. 1986. Ice nucleation and supercooling in freeze-sensitive peach and sweet cherry tissues. $J$. Amer. Soc. Hort. Sci. 11:232-236.

Boyce,B.R., A.L. Hazelrigg, and A.W. Linde. 1985. Field evaluation of loss of primary or primary and secondary blossoms on strawberry fruit weight and yield. Adv. Strawberry Prod. 4:32-33.

Boyce, B.R. and J.B. Strater. 1984. Comparison of frost injury in strawberry buds, blossoms and immature fruit. Adv. Strawberry Prod. 3:8-10.

Burke, M.J., L.V. Gusta, H.H. Quamme, C.J. Weiser, and P.H. Li. 1976. Freezing and injury in plants, p. 507-528. In: W.R. Briggs, P.B. Green, and R.L. Jones (eds.). Annual review of plant physiology. vol. 27. Annual Reviews, Palo Alto, Calif.

Gross, D.C., E.L. Proebsting, Jr., and P.K. Andrews. 1984. The effects of ice nucleation-active bacteria on temperatures of ice nucleation and freeze injury of Prunus flower buds at various stages of development. J. Amer. Soc. Hort. Sci. 109:375-380.

Hirano, S.S., L.S. Baker, and C.D. Upper, 1985. Ice nucleation temperature of individual leaves in relation to population sizes of ice-nucleationactive bacteria and frost injury. Plant Physiol. 77:259-265.

Janick, J. and C.A Eggert. 1968. Factors affecting fruil size in the strawberry. Proc. Amer. Soc. Hort. Sci. 93:311-316.

Ki, W.K. and M.R. Warmund. 1992. Low temperature injury to strawberry floral organs at several stages of development. HortScience 27:1302-1304.

Lindemann, J. and T.V. Suslow. 1987. Competition between ice-nucleation-active wild type and ice-nucleation-deficient deletion mutant strains of Pseudomonas syringae and P. fluorescens Biovar I and biological control of frost injury on strawberty blossoms. Phytopathology $77: 882-886$.

Lindow, S.E. 1983. The role of bacterial ice nucleation in frost injury to plants. Annu. Rev. Phytopathol. 21:363-384.

Lindow, S.E., D.C. Arny, and C.D. Upper. 1978a. Distribution of icenucleation-active bacteria on plants in nature. Appl. Environ. Microbiol. 36:831-838.

Lindow, S.E., D.C. Arny, and C.D. Upper. 1978b. Erwinia herbicola: A bacterial ice nucleus active in increasing frost injury to corn. Phytopathol. 68:523-526.

Lindow, S.E., D.C. Arny, and C.D. Upper. 1982a. Bacterial ice nucleation: A factor in frost injury to plants. Plant Physiol. 70:1084-1089.

Lindow, S.E., S.S. Hirano, W.R. Barchet, D.C. Arny, and C.D. Upper. 1982b. Relationship between ice nucleation frequency of bacteria and frost injury. Plant Physiol. 70: 1090-1093.

Maki, L.R., E.L. Galyan, M.M. Chang-Chen, and D.R. Caldwell. 1974. Ice nucleation induced by Pseudomonas syringae. Applied Microbiol. $456-459$.

Snedecor, G.W. and W.G. Cochran. 1989. Statistical methods. 8th ed. Iowa State Univ. Press, Ames.

Warmund, M.R., F. Takeda, and G.A. Davis. 1992. Supercooling and extracellular ice formation in differentiating buds of eastern thornless blackberry. J. Amer. Soc. Hort. Sci. 117:941-945.

Warmund, M.R. and J.T. English. 1995. Freezing injury and colonization of 'Redwing' raspberries with ice-nucleation-active bacteria. J. Amer. Soc. Hort. Sci. 120: 1041-1044. 